\title{
Anthós
}

4-2010

\section{Breaking the Cycle of Big Man Rule in Africa}

Corey Watson

Portland State University

Follow this and additional works at: https://pdxscholar.library.pdx.edu/anthos

Part of the Other Political Science Commons

Let us know how access to this document benefits you.

\section{Recommended Citation}

Watson, Corey (2010) "Breaking the Cycle of Big Man Rule in Africa," Anthós: Vol. 2: Iss. 1, Article 5. https://doi.org/10.15760/anthos.2010.40

This open access Article is distributed under the terms of the Creative Commons Attribution-NonCommercialShareAlike 4.0 International License (CC BY-NC-SA 4.0). All documents in PDXScholar should meet accessibility standards. If we can make this document more accessible to you, contact our team. 


\section{Breaking the Cycle of Big Man Rule in Africa}

Corey Watson

Undergraduate of Political Science, Mark O. Hatfield School of Government

Portland State University 



\section{Introduction}

Despite coup after coup across a large number of diverse countries on the continent of Africa, each new leader resembles similar levels of what Martin Meredith (2005) describes as "corruption, mismanagement, tribalism, nepotism, and other assorted malpractices" as the leader before him (p. 219). Africans either are not able to see this pattern because of the subjective uniqueness across their singular experiences, or they do see the pattern and are simply unable to break from the cycle. This paper reviews the contributions of Martin Meredith and Goran Hyden (2006) to ask why Big Man rule exists in Africa.

Africa in this paper refers to the region south of the Sahara Desert, which is also called sub-Sarahan Africa. "Big Man" rule holds a significant place in the literature on how the region governs itself. It can be defined as a form of autocratic rule that is highly personalized and restrained little by modern institutions, which has the effect of making the "supremacy of politics" in Africa extremely risky with high stakes for those who engage in the process and a great degree of uncertainty for the public in general (Hyden, 2006, p. 94). Each author contributes a different perspective to answer why Big Man rule is purely an African phenomenon. Hyden, in his book African Politics in Comparative Perspective, offers a theoretical perspective that outlines a typology of Big Man rule, provides three theoretical arguments worth exploring, and reviews the process of constitution-building in the region. Accompanying the theoretical will be Meredith's (2005) historical perspective from his book The Fate of Africa, which will be compared and contrasted with Hyden's (2006) arguments to derive a more grounded answer to this paper's query.

The paper is divided into three sections. First, I will use Hyden's (2006) explanation for the origins of Big Man rule in Africa and argue that the historical legacy argument has little utility for providing a solution. Second, I will ask what Hyden's typology reveals about Big Man rule. The types of rule are outlined as prophets, princes, autocrats, and tyrants. This particular ordering is necessary to understand the key causal variable underlying their differences: legitimacy. Comparing this typology with Meredith's (2005) biography and description of the personality of leaders will create a more satisfying explanation. And third, I will explore the three theoretical concepts Hyden (2006) provides to explain why Big Man rule seems to be unique to Africa: free riding, coalition-building, and transaction costs. I will conclude with a short summary of the expected policy implications to this understanding of Big Man rule.

\section{Historical Legacy}

Big Man rule in Africa is highly personal. Hyden (2006) quotes Max Weber's description of patrimonialism, which appears very similar to Big Man rule: "The patrimonial office lacks above all the bureaucratic separation of the 'private' and 'official' sphere. For the political administration, too, is treated as a purely personal affair of the ruler, and political power is considered part of his personal property" (p. 95). Hyden notes that few patrimonial rulers survived colonization, but also that scholars realized that "despite the disappearance of patrimonial system of rule in Africa, the norms associated with such systems survived among the leaders of the new nation-states" (p. 96). According to Hyden, 
this leads to the state of "neopatrimonialism" (p. 96). Whether by historical memory or colonial imitation, I believe this historical theory has limited utility for policy. Path dependency arguments like these offer little advise other than promoting education and a policy of watchful waiting to reverse such trends. While these policies are likely to be necessary for a transition from Big Man rule, they are by no means original contributions or have a high probability for successful implementation. As I will show, Hyden and Meredith (2005) offer explanations with more utility by looking inside the incentive structure and personalities of Big Man rule.

\section{Big Man Typology}

Why are some rulers more corrupt than others? Why are some rulers more accommodating to those around them, while others more coercive? Why is tribalism and nepotism so prevalent? These are just a few of the questions that are necessary to explain the existence of Big Man rule. First, let's begin with a simple assumption: Those who do not have power want it, and those who have power want to keep it. Both Hyden (2006) and Meredith (2005) recognize this assumption in their discussion of the lengths to which rulers protect their power from others. A ruler cannot be everywhere and know everything, so they depend a great deal on those around him. However, those around him cannot always be trusted to remain loyal. Some might not follow orders and some might even conspire against the ruler. There are various strategies that rulers take to protect their power from such eventualities. Virtually every ruler carefully selects those he is surrounded by based on the potential for loyalty, often at the expense of competence. This can be family members, members from his tribe, or members from his hometown. Some rulers peacefully play off the ambitions of these loyalists, some pay them off, some rotate them in and out of power, some rule by fear and coercion, and some simply trust them. A ruler also has to take into account the attitude of the public. If the ruler believes he is not either respected or feared by the public, then he is likely to view them as a threat to his rule. Thus, he strategizes for this eventuality by either manufacturing legitimacy or ruling violently. Sometimes the taming of loyalists conflicts with the appeasement of the public. Hyden (2006) offers a way to sort through these various reactions by rulers to protect power.

Hyden (2006) offers the typology developed by Robert Jackson and Carl Rosberg, which consists of prophets, princes, autocrats, and tyrants (p. 99). This is ordered from high public legitimacy / low personal security to low public legitimacy / high personal security. When public legitimacy is high, rulers have more freedom to provide public goods, but when public legitimacy is low, rulers must concentrate more on private goods to survive politically. When personal security is low, rulers are at a greater subjective risk of subversion, but when personal security is high, rulers are at a lower subjective risk of subversion.

At the highest level of public legitimacy and lowest level of personal security are prophets. Hyden (2006) describes them as "visionaries wanting to reshape African society" (p. 99). He continues to describe that their challenge is greater than other types of rule because "not only have they faced the task of maintaining political order but they have placed themselves in a position where they are expected to steer the ship in a desired ideological destination and mark off some recognizable progress 
in that direction" (p. 99). This makes prophets a minority because "raising expectations to high levels was tantamount to political suicide for the prophets" (p. 100). Julius Nyerere of Tanzania is a telling example of the prophet. Hyden describes that, "His puritan way of life, combined with his persuasive rhetoric, allowed him to rule during much of the 1970s without resorting to massive misuse of government funding" (p. 102-103). In other words, Nyerere had high public legitimacy. While the method that prophets use to maintain power is stable at the public-level, it is subjectively unstable at the private-level. So long as a vision does not fail, it is able to keep a prophet in power by keeping people hopeful and sustaining a base for the extraction of resources, but it does not alleviate the uncertainty of subversive elements within the administration. This reveals two choices for personal rulers, gain public legitimacy or gain personal security. Prophets choose the former at the expense of the latter. Thus, the opportunity cost of the choice between gaining public legitimacy and gaining personal security determines the type of rule.

To further this conception, consider Hyden's (2006) "princes":

The prince is a clever observer and manipulator of lieutenants and clients. He tends to rule jointly with others by presiding over their struggle for benefits, encourage it, and recognize that it is the source of his own legitimacy. Princely rule is sufficiently flexible to allow for a politics of accommodation. (p. 99)

The key descriptor that defines a prince from other types of rule is "sufficiently flexible." A prince has only a moderately-high amount of public legitimacy because he has traded some of it for personal security. Meredith (2005) highlights these elements in his chapter on Emperor Haile Selassie of Ethiopia. Selassie had both historical and divine legitimacy.

His defiant stand against Mussolini's brutal invasion in the 1930s had won him worldwide fame. Restored to his throne in the 1940s, he stood as the symbol of an independent Africa that nationalist leaders living under colonial rule all aspired to achieve. His position as monarch of a state that traced its origins back to biblical times ... According to the Ethiopian constitution, the emperor was descended directly from the marriage of Solomon and Sheba, and among the titles with which he was graced was that of 'Elect of God'. (p. 206)

This legitimacy was made consistent by the use of traditions, religious ceremonies, and Selassie's name on everything from schools to bridges. However, he was not afraid to use public funds for sustaining his personal rule. "What helped to sustain his power was the considerable extent to which the emperor, together with the Coptic Church and influential aristocratic families in the provinces, owned and controlled land and thereby the livelihood of millions of peasants who worked it" (p. 207). Peasants were required to pay 75 percent of their produce to landlords and provide seemingly unlimited unpaid services (p. 207). To this end, Selassie "governed as an autocratic monarch, dispensing titles, appointments and land in return for loyal service, and holding together the empire of its 27 million subjects through a vast network of personal ties" (p. 207). Selassie, and princes in general, thus possess enough public legitimacy to extract resources from their population, but also use the funds from which to dole out goodies to those who can promise personal security.

On the other end of the spectrum are autocrats and tyrants. Hyden (2006) describes autocrats in light of princes. 
Autocrats differ from princes in that they command and manage rather than preside and rule. The country is the ruler's estate and the state apparatus is ultimately his to use at his own discretion. Party and government officials are essentially his servants and agents. Any limitations that he faces to his rule are the result of shortage of resources or lack of organizational ability, not the absence of discretionary power. (p. 99)

There appears to be more concern for gaining personal security as an autocrat, which explains the more hands-on style of rule. There also appears to be less of a concern for gaining public legitimacy because only a lack of resources or organizational ability can limit an autocrat's power. This last observation is the key differentiation between the autocrat and the tyrant. Autocrats could easily become tyrants if they were not limited by restraints. Historically, such restraints have been the context of at least a nominal democracy, a strong civil society, or a well-performing economy. These three factors make the autocrat dependent on a modicum of legitimacy. While he might use strong-arm political tactics like manipulating elections to sustain his rule, he cannot use brutality, at least too openly, to silence dissent for fear of popular revolt. Meredith's (2005) description of Moi arap Daniel's rule of Kenya offers an example of this "soft-authoritarianism." "In Kenya the risks of speaking out publicly against Moi's regime were well known. Arrest, detention and other forms of harassment — for journalists, academics, trade unionists and even members of parliament - were the most likely outcome" (p. 400). Moi's regime was strongly opposed to multi-party elections, as this would undermine his one-party rule, but his weakness was that his government was so dependent on foreign aid. In an attempt to suppress a movement that called for multi-party politics, Moi's regime began an ethnic cleansing campaign to rid the Rift Valley province of any tribe that supported the movement (p. 402). In response, Western donors suspended Kenya's "balance of payments support and other rapid disbursement aid" for six months (p. 402). Moi immediately capitulated by announcing that "he intended to lift the ban on opposition parties and hold multi-party elections" (p. 403). Whether these new elections were manipulated is beside the point. Moi was clearly restrained from more brutal measures to maintain power, which sets him apart from tyrants.

Hyden (2006) describes tyrants as the most oppressive. "Tyrants rule through fear. They reward agents and collaborators and turn them into mercenaries. Tyranny, in short, is marked by particularly impulsive, oppressive, and brutal rule that lacks elementary respect for the rights of persons and property" (p. 100). Hyden considers tyrants a residual category that leaders need not start as, but eventually end up as (p. 100). However, according to this paper's formulation of the typology, none of the types of Big Man rule need to be static and all could be considered residual categories of the others. The types vary with the opportunity cost of public legitimacy and personal security. Perhaps a prophet could transition into a tyrant and a tyrant into a prophet. Empirically such cases are difficult to support, but President Kerekou of Benin's transformation from a military autocrat to a civilian ruler as the country transitioned to a democracy gives support for movement among the typology (p. 100).

Why does a tyrant rule through fear and coercion? There seems to be a more desperate need for personal security among tyrants than among the other types of rule. Meredith's (2005) discussion of Idi Amin of Uganda is constructive in this regard. After Amin's ouster of Milton Obote, the coup was greeted with "relief and enthusiasm" (p. 234). 
Yet Amin never felt secure. Fearing a counter-attack by Obote supporters, he organized death squads to hunt down and kill scores of army and police officers he suspected of opposing him. Within a few months, mass killing of Langi and Ancholi began. (p. 234)

The structural explanation of tyrants, however, has its limits. Because tyrannical rule is so separated from public legitimacy, it is highly sensitive to the personality of the ruler. This is where Hyden's (2006) theoretical perspective fails and Meredith's (2005) biographical perspective is more applicable. Describing Abeid Karume of Zanzibar's incoherent formulation of policies, Meredith recognizes his policies "more and more came to depend on his erratic and capricious personality" (p. 223-224). For example:

He banned contraceptives; forced 'volunteers' to undertake farmwork; closed private clubs and abolished private business and trading enterprises. He expelled staff from the World Health Organization and suspended malaria-control programs on the grounds that Africans were 'malaria-proof,' precipitating a huge surge in malaria. (p. 224)

Hyden (2006) might point out that these are perfectly rational behaviors and can be explained by looking closer at the incentive structure. However, I would add a caveat: These are not fully rational behaviors, because some of them reflect more personal rationality than institutional rationality. Looking purely at the institutional mechanisms such that Hyden might would provide a limited explanation for why private clubs and private businesses were closed. Looking closer at Meredith's (2005) biography of Karume is much more fulfilling: "Distrustful of intellectuals and disliking experts" (p. 223). Meredith's simple statement of Karume's personal distrust of intellectual elements seems to better explain the leader's activities against contraceptives, private clubs, and private business than does Hyden's (2006) institutional approach.

The most instructive of Meredith's (2005) contributions to the nature of tyrants is the background he provides for each. Describing Jean-Bedel Bokassa of the Central African Republic:

From an early age, Bokassa's life was affect by violence. When he was six years old, his father, a petty chief in the village of Boubangui was beaten to death at the local French prefect's office for protesting against forced labor. His distraught mother killed herself a week later, leaving a family of twelves children as orphans. (p. 224)

As well as tragic childhoods, tyrants often share low levels of education. Karume's distrust of intellectuals is likely rooted in him having "little formal education" (p. 222). Francisco Macias Nguema of Equatorial Guinea shared similar characteristics. “. . . a politician of limited education and low mental ability ... . while being groomed for office by the Spanish, Nguema harbored intense resentments against them and an abiding hatred of foreign culture and 'intellectuals' in general. Once in power, he lashed out" (p. 239). As for Idi Amin, his "proclivity for violent conduct became a matter of controversy" (p. 231). "While participating in a military operation in Kenyas Northern Frontier District, Amin was accused of murdering three Turkana tribesmen" (p. 231-232). To make matters worse, similar to Karume and Nguema, Amin was "virtually illiterate, with no schooling and limited intelligence" (p. 231). And again, Mengistu Haile Mariam of Ethiopia had "little formal education" as well as being "placed in the army as a 'boy' at the age of fifteen" (p. 243). In fact, most of the tyrants Meredith discusses come from military backgrounds. A violent background, however, need not be the 
only determinant of tyrannical rule, but when it is existent within the right incentive structure, it can be a powerful predictor.

\section{Why Africa?}

The ordering of the typology that Hyden (2006) provides has revealed legitimacy to be an important variable in explaining the nature of Big Man rule. When rulers choose to gain personal security at the expense of public legitimacy, their rule becomes more coercive and their people become less prosperous. But this leaves an important question unanswered: Why is this trade-off so prevalent in Africa?

In an ideal situation, public legitimacy would be recycled by extracting resources from the public and converting it into public goods. But somewhere along this cycle, African rulers fail. Prophets have achieved a high level of legitimacy, but in the case of Nyerere's efforts to transition his country into a socialist economy, this legitimacy has failed to extract resources properly to convert into public goods. Princes have achieved a moderately-high level of legitimacy and successfully extracted resources from their people, such as Emperor Selassie, but chose not to convert these resources into many public goods; and instead, into mostly private goods. And autocrats and tyrants have achieved a very limited level of legitimacy, but were unable to extract enough resources to use for public goods conversion; and instead, could only extract enough to use for private goods. This pattern reveals three different failures along the legitimacy cycle: administrative ability, choice, and the capacity for legitimacy. Because autocrats and tyrants are much more prevalent in Africa, it is important to ask why the capacity for legitimacy becomes so limited.

Hyden's (2006) discussion of three theoretical arguments is extremely helpful on this point. He identifies three interrelated factors: free riding, coalition-making, and transaction costs. He describes free riding, "Whenever individual choice is treated as independent of what others choose, there is always the possibility for free riding, that is, the assumption that a person does not need to contribute anything in order to benefit from what others do" (p. 101). In other words, people have the freedom to benefit from the actions of the collective. However, this is not so in Africa. Because relations are so highly personal and based on direct reciprocal relations, there is no opportunity to free ride. People

must fend for themselves. "This orientation toward clientelist relations as a key premise of politics creates a dynamic in which free riding is ruled out" (p. 102). The consequences of this dynamic is that politics becomes costly, highly opportunistic, and most importantly, risky.

When the informal institutions of clientelism and the "economy of affection" penetrate so many levels of society, politics becomes more about individual pay-offs than collective pay-offs. Big Man rule is no different in this regard. If nobody is being paid for their loyalty to the Big Man, then there is no incentive to remain loyal. Meredith's (2005) opening to his chapter on tyrants is a perfect example:

In 1967 a 27-year-old Ghanaian army lieutenant, Sam Arthur, finding himself in temporary command of an armored car unit, decided on an attempt to seize power because, he later confessed, he wanted to 'make history' by becoming the first lieutenant successfully to organize a coup. The coup attempt was given the name 'Operation Guitar Boy'. Arthur's armored car unit drove into Accra but failed to gain control. (p. 218) 
With so many people expecting to be paid for their loyalty, remaining in power can become very expensive for the Big Man. This incentivizes the building of a maximum-sized coalition, instead of a minimum-sized one as rational choice theory posits (Hyden, 2006, p. 103), because it only takes one ambitious lieutenant to convince the coalition that he could better serve their interests. But, as Hyden summarizes in surprise, "the broader the support base, the more powerful the ruler and the more stable the system!” (p. 103-104).

Complicating matters, Hyden (2006) adds that the transaction costs of holding the large coalition together requires, "The personal accumulation of resources by the ruler . . . in order to sustain these relations” (p. 104). Meredith's (2005) chapter on Mobutu Sese Seko of Zaire exemplifies this excessive accumulation of a personal fortune:

Mobutu's personal fortune grew in leaps and bounds. During the 1970s it was estimated that one-third of total national revenues was in one way or another at his disposal. He used the central bank at will for his own purposes. (p. 298)

Failing to safeguard resources means a split in the coalition and a risk of opportunism.

What does this mean for the maintenance of public legitimacy in Africa to sustain rule? That, as Hyden (2006) describes it, the "window of opportunity" is very short (p. 103).

Leaders who are fresh in power do not have to institutionalize the networks of clients that typify personal rule immediately because they can ride the euphoric wave of victory. Followers are anxiously awaiting the ruler's decisions and in that transitional moment-the honeymoon period-there is scope for attention to policy and the need to legitimize the new regime in the eyes of the international community. The point, however, is that this window of opportunity disappears sooner rather than later and clientelist relations begin to call for more of the ruler's attention. (p. 103)

Africa, thus, seems to have no stable source of legitimacy to extend this window any further, staving off deterioration to Big Man rule. This brings us to a simple conception of understanding how Big Man rule is created and sustained: Unstable legitimacy and the prevalence of informal institutions creates Big Man rule and a stable personal fortune sustains it. When one of these variables do not exist, there is no Big Man. Stable legitimacy means a proper recycling of it. Formal institutions means less uncertainty in political security. And an unstable personal fortune means a very short-lived Big Man.

\section{Conclusion}

The contributions of Hyden (2006) and Meredith (2005) to the understanding of Big Man rule has developed, what I believe, to be a significant improvement from the historical legacy explanation. The conceptualization derived from these readings helps to determine what to expect from different policy options. We should expect that the consolidation of constitutionalism would formalize institutions and remove a necessary condition for the creation of a Big Man. Likewise, designing policies to concentrate on the three elements of the legitimacy cycle to stabilize it would eliminate another necessary condition. What we should not expect is anti-corruption policies to make much of an impact, because even if they were effective, they would only shorten the survival of Big Men, not keep them from coming to power. 
Thus, stabilizing legitimacy or formalizing institutions has the highest utility to breaking the cycle of Big Man rule. 


\section{References}

Hyden, G. (2006). African Politics in Comparative Perspective. Cambridge, MA: Cambridge University Press. Meredith, M. (2005). The Fate of Africa: A History of Fifty Years of Independence. New York, NY: PublicAffairs. 